\title{
A Flexible Portable Glucose Sensor Based on Hierarchical Arrays of $\mathrm{Au} @ \mathrm{Cu}(\mathrm{OH})_{2}$ Nanograss
}

\author{
Min Jiang ${ }^{1}$, Peng Sun ${ }^{2,3}$, Jie Zhao ${ }^{1, *}$, Lihua Huo ${ }^{4, *}$ and Guofeng Cui ${ }^{2,3, *}$ \\ 1 School of Mechanical and Automotive Engineering, South China University of Technology, \\ Guangzhou 510640, China; mejiangmin@mail.scut.edu.cn \\ 2 Key Laboratory for Polymeric Composite \& Functional Materials of Ministry of Education, School of \\ Chemistry, Sun Yat-sen University, Guangzhou 510275, China; sunp25@mail2.sysu.edu.cn \\ 3 MOE Laboratory of Bioinorganic and Synthetic Chemistry, The Key Lab of Low-Carbon Chemistry and \\ Energy Conservation of Guangdong Province, School of Chemistry, Sun Yat-sen University, 135, \\ Xingang West Road, Guangzhou 510275, China \\ 4 Key Laboratory of Functional Inorganic Material Chemistry, Ministry of Education, School of Chemistry and \\ Materials Science, Heilongjiang University, Harbin 150080, China \\ * Correspondence: zhaoj77@scut.edu.cn (J.Z.); huolihua@hlju.edu.cn (L.H.); cuigf@mail.sysu.edu.cn (G.C.)
}

Received: 9 October 2019; Accepted: 15 November 2019; Published: 19 November 2019

check for updates

\begin{abstract}
Flexible physiological medical devices have gradually spread to the lives of people, especially the elderly. Here, a flexible integrated sensor based on Au nanoparticle modified copper hydroxide nanograss arrays on flexible carbon fiber cloth $\left(\mathrm{Au} @ \mathrm{Cu}(\mathrm{OH})_{2} / \mathrm{CFC}\right)$ is fabricated by a facile electrochemical method. The sensor possesses ultrahigh sensitivity of $7.35 \mathrm{~mA} \mathrm{mM} \mathrm{m}^{-1} \mathrm{~cm}^{-2}$ in the linear concentration range of 0.10 to $3.30 \mathrm{mM}$ and an ultralow detection limit down to $26.97 \mathrm{nM}$. The fantastic sensing properties can be ascribed to the collective effect of the superior electrochemical catalytic activity of nanograss arrays with dramatically enhanced electrochemically active surface area as well as mass transfer ability when modified with $\mathrm{Au}$ and intimate contact between the active material $\left(\mathrm{Au} @ \mathrm{Cu}(\mathrm{OH})_{2}\right)$ and current collector (CFC), concurrently supplying good conductivity for electron/ion transport during glucose biosensing. Furthermore, the device also exhibits excellent anti-interference and stability for glucose detection. Owing to the distinguished performances, the novel sensor shows extreme reliability for practical glucose testing in human serum and juice samples. Significantly, these unique properties and the soft structure of silk fabric can provide a promising structure design for a flexible micro-device and a great potential material candidate of electrochemical glucose sensor.
\end{abstract}

Keywords: $\mathrm{Cu}(\mathrm{OH})_{2}$ nanograss; Au nanoparticles; glucose detection; flexible electrochemical biosensor

\section{Introduction}

Diabetes mellitus, also known as the disease of affluence, is caused by both genetic and environmental factors. Currently, there is no radical cure for diabetes, but it can be controlled by various treatments. It will cause many serious complications when not diagnosed and treated in time [1]. One effective way to prevent such dire consequences is to monitor blood sugar levels accurately on a daily basis. Therefore, a flexible glucose sensor with high reliability and portability is particularly important [2,3]. However, most studies have focused on the preparation and application of flexible glucose sensor materials [4-7] and integrating flexible non-enzymatic glucose sensors has rarely been reported before.

For a flexible sensor, it is equally important to fabricate a flexible electrode material and a flexible substrate such that the final sensor can be applied to a curved surface, e.g., a surface in the human body. In this aspect, carbon fiber cloth is a very ideal electrochemical flexible substrate, which has excellent electrical conductivity for deposition of active substances and soft structure of silk fabric to meet wearable needs. In addition, its macroporous structure provides a fast transport path for ions 
and accelerates the diffusion of electrolytes in the electrode material [8]. More importantly, research shows that electrochemical material electrodes using carbon fiber cloth as a substrate have a larger electrochemically active surface area and higher utilization of active materials, compared to applying other common substrates $[9,10]$. Based on the above, this paper selects and uses carbon fiber cloth as the substrate to make flexible glucose sensors.

Enzyme glucose sensors have matured over three generations, but their own fatal shortcomings, such as poor stability and high cost [11,12], have led to extensive research on non-enzyme glucose sensors [13,14], for which non-enzymatic catalytic material is a most vital factor. Because the microstructures of catalytic materials, including surface area, porosity, special structure, etc., have close contact with their biocatalytic activity $[15,16]$, various nanostructured catalytic materials for non-enzyme glucose sensors have been widely studied, such as nanoporous metal ( $\mathrm{Au}, \mathrm{Pt}, \mathrm{Cu}$, etc. [17-19]) and metal oxides/ hydroxides $\left(\mathrm{CuO}, \mathrm{Ni}(\mathrm{OH})_{2}, \mathrm{Co}_{3} \mathrm{O}_{4}\right.$, etc. [20-23]) and nanocomposites ( $\mathrm{Pt}-\mathrm{CuO}, \mathrm{ZnO}-\mathrm{CuO}, \mathrm{Co}_{3} \mathrm{O}_{4}-\mathrm{PbO}_{2}$, etc. $[9,24,25])$. Among them, the nanocomposites of noble metal with the copper oxides are excellent materials for non-enzymatic glucose sensors, due to it possessing the properties of stable, low cost and high catalytic activity of copper oxides and its catalytic performance being further enhanced by noble metal [3,24,26-28]. For copper-based non-enzyme glucose sensors, the possible electrocatalytic mechanism of glucose oxidation has been attributed to the mediation by $\mathrm{Cu}(\mathrm{OH})_{2} / \mathrm{CuOOH}[29,30]$. Thus, it can be better to fabricate copper hydroxide electrode materials instead of copper oxides for glucose detection. However, there are only a few works on copper hydroxide electrode research and they have also demonstrated improved catalytic performance for glucose [30-32]. Even more regrettably, there is no nanocomposite material of noble metal-copper hydroxide. In addition, the noble metal-copper oxides sensing catalyst is fabricated by a one step chemical process and immobilized on hard substrates such as the screen printed electrodes and glassy carbon electrodes $[24,27,28]$. But the chemical syntheses are usually energy-consuming and could result in impurities that hinder glucose sensing [6]. In contrast, the electrochemical synthesis provides a facile method to fabricate the oxides and hydroxides of copper and deposit noble metal on the flexible substrates [20,33,34].

In this paper, we produced flexible electrodes on carbon fiber cloth (CFC) by a facile electrochemical method, such as the working electrode of Au nanoparticle modified copper hydroxide nanograss arrays $\left(\mathrm{Au} @ \mathrm{Cu}(\mathrm{OH})_{2} / \mathrm{CFC}\right)$, counter electrode of $\mathrm{Pt} / \mathrm{CFC}$ and reference electrode of $\mathrm{Ag} / \mathrm{AgCl} / \mathrm{CFC}$. Compared to the previous chemical method [35-37], this method greatly shortens the electrode preparation time, saves energy and especially makes the electrochemical material pure. Moreover, the three electrodes are assembled on a polytetrafluoroethylene (PTFE) film simultaneously to make a flexible micro-sensor. The novel sensor possesses excellent performance in glucose sensing. Significantly, the sensor possesses flexible properties and shows ultrahigh sensitivity of $7.35 \mathrm{~mA} \mathrm{mM}{ }^{-1} \mathrm{~cm}^{-2}$ in the linear glucose concentration range of 0.10 to $3.30 \mathrm{mM}$. Meaningfully, the obtained device shows extreme reliability for practical glucose testing in human serum and juice samples, which makes it a good application prospect for flexible non-enzyme glucose sensors.

\section{Materials and Methods}

\subsection{Reagents and Chemicals}

Carbon fiber cloth (CFC) was purchased form Kunshan Tengerhui Electronic Technology Co., Ltd. (W0S1002). Copper (II) pyrophosphate $\left(\mathrm{Cu}_{2} \mathrm{P}_{2} \mathrm{O}_{7}\right)$, potassium pyrophosphate $\left(\mathrm{K}_{4} \mathrm{P}_{2} \mathrm{O}_{7}\right)$, ammonium citrate $\left(\mathrm{C}_{6} \mathrm{H}_{17} \mathrm{~N}_{3} \mathrm{O}_{7}\right)$, citric acid $\left(\mathrm{C}_{6} \mathrm{H}_{8} \mathrm{O}_{7}\right), \mathrm{Na}_{2} \mathrm{SO}_{4}, \mathrm{HCl}(36 \%)$ and $\mathrm{KOH}$ were purchased from Xilong Chemical Co., Ltd. (Guangzhou, China). Chloroauric acid $\left(\mathrm{HAuCl}_{4}\right)$, chloroplatinic acid $\left(\mathrm{H}_{2} \mathrm{PtCl}_{6}\right)$, potassium chloride (KCl), $\beta$-D-glucose (glucose), uric acid (UA, > 99\%), dopamine (DA, $>98 \%$ ), ascorbic acid (AA, > 99\%), maltose, fructose, cysteine (Cys) and 4-acetamidophenol (4-AP) were received from Aladdin Company. $\mathrm{AgNO}_{3}, \mathrm{Na}_{2} \mathrm{~S}_{2} \mathrm{O}_{3} \cdot 5 \mathrm{H}_{2} \mathrm{O}, \mathrm{K}_{2} \mathrm{~S}_{2} \mathrm{O}_{5}, \mathrm{NH}_{4} \mathrm{Ac}$ and $\mathrm{CH}_{5} \mathrm{~N}_{3} \mathrm{~S}$ were purchased from Mclin Biochemical Technology Co., Ltd. All chemicals were of analytical grade without further purification. The human serum sample was obtained from Beijing Solarbio Science \& Technology Co., Ltd. (Beijing, 
China) and the mulberry drink (Bosun) was purchased from a supermarket. Poly-tetra prone (PTFE) film and nano-double-sided tape were purchased from Jincheng Plastic Co., Ltd. and Qichen Office Supplies (Shenzhen) Co., Ltd., respectively.

\subsection{Preparation of $\mathrm{Cu} / \mathrm{CFC}$}

Firstly, carbon fiber cloth was immersed in $68 \%$ nitric acid at $90{ }^{\circ} \mathrm{C}$ for $30 \mathrm{~min}$ and then immersed into a $1 \mathrm{M} \mathrm{KOH}$ solution for $10 \mathrm{~min}$ to improve hydrophilic and remove organic binder on its surface. Then the processed carbon fiber cloth was stored in ethanol solution for later electrodeposition. Finally, the $\mathrm{Cu}$ film was electrodeposited on the processed carbon fiber cloth under $4 \mathrm{ASD}\left(\mathrm{A} \mathrm{dm}^{-2}\right)$ at $35^{\circ} \mathrm{C}$ for $15 \mathrm{~min}$ and with a continuous stirring of $300 \mathrm{rpm}$, in which the copper plating solution was composed of $65 \mathrm{~g} \mathrm{~L}^{-1} \mathrm{Cu}_{2} \mathrm{P}_{2} \mathrm{O}_{7}, 380 \mathrm{~g} \mathrm{~L}^{-1} \mathrm{~K}_{4} \mathrm{P}_{2} \mathrm{O}_{7}$ and $22.5 \mathrm{~g} \mathrm{~L}^{-1} \mathrm{C}_{6} \mathrm{H}_{17} \mathrm{~N}_{3} \mathrm{O}_{7}$; the $\mathrm{pH}$ should be adjusted to 8.8 with citric acid.

\subsection{Preparation of $\mathrm{Au} @ \mathrm{Cu}(\mathrm{OH})_{2} / \mathrm{CFC}, \mathrm{Pt} / \mathrm{CFC}$ and $\mathrm{Ag} / \mathrm{AgCl} / \mathrm{CFC}$}

The subsequent preparations were performed in a three-electrode system at $25{ }^{\circ} \mathrm{C}$, in which commercial $\mathrm{Pt}$ foil and an $\mathrm{Ag} / \mathrm{AgCl}(3 \mathrm{M} \mathrm{KCl})$ electrode were used as counter electrode and reference electrode, respectively. After being washed with deionized water, the $\mathrm{Cu} / \mathrm{CFC}$ electrode was immersed into $50 \mathrm{~mL} 1 \mathrm{M} \mathrm{KOH}$ solution and then immediately scanned three times with a linear sweep voltammetry (LSV) under the potential range from -0.40 to $0.40 \mathrm{~V}$ at $3 \mathrm{mV} \mathrm{s}^{-1}$ to oxidize the $\mathrm{Cu}$ on the $\mathrm{CFC}$ to $\mathrm{Cu}(\mathrm{OH})_{2}$. Then, the obtained $\mathrm{Cu}(\mathrm{OH})_{2} / \mathrm{CFC}$ electrode, after being rinsed with pure water, was put into a solution containing $1 \mathrm{mM} \mathrm{HAuCl}_{4}$ and $0.1 \mathrm{M} \mathrm{KCl}$ under a constant potential of $-0.20 \mathrm{~V}$ for $180 \mathrm{~s}$ to electrodeposit Au nanoparticles to the surface of $\mathrm{Cu}(\mathrm{OH})_{2} / \mathrm{CFC}$, that is, the $\mathrm{Au} @ \mathrm{Cu}(\mathrm{OH})_{2} / \mathrm{CFC}$ electrode was obtained. The synthesized processes were also illustrated in the scheme of Figure 1 and Figure S1 shows the corresponding optical images, from which it can be found that the color of the electrodes changes significantly at each stage (except the process of Au deposition). For comparison, an $\mathrm{Au} / \mathrm{CFC}$ electrode was also prepared by employing the same electrodeposition procedure on CFC directly.

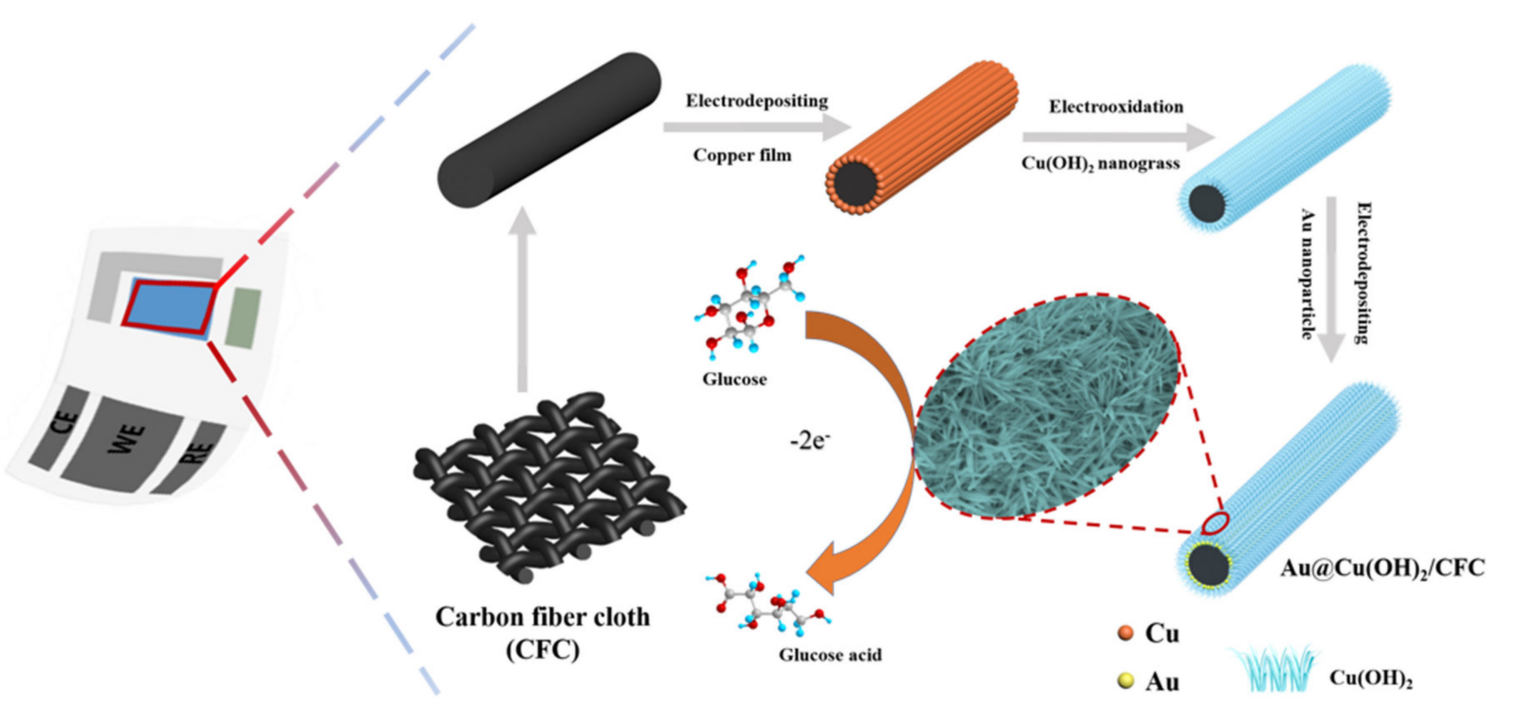

Figure 1. Schematic illustration of the fabrication process for the Au nanoparticle modified copper hydroxide nanograss arrays on flexible carbon fiber cloth $\left(\mathrm{Au} @ \mathrm{Cu}(\mathrm{OH})_{2} / \mathrm{CFC}\right)$ electrode and the corresponding detection mechanism.

In our previous work, we fabricated a $\mathrm{Pt}$ counter electrode and an $\mathrm{Ag} / \mathrm{AgCl}$ reference electrode $[3,38]$. In this paper, the same electrochemical method was used to fabricate the $\mathrm{Pt} / \mathrm{CFC}$ and $\mathrm{Ag} / \mathrm{AgCl} / \mathrm{CFC}$. It is worth noting that after open circuit potential testing the $\mathrm{Ag} / \mathrm{AgCl} / \mathrm{CFC}$ electrode can be fully usable (Figure S2, Appendix A). 
The obtained $\mathrm{Cu}(\mathrm{OH})_{2} / \mathrm{CFC}$, $\mathrm{Au} @ \mathrm{Cu}(\mathrm{OH})_{2} / \mathrm{CFC}, \mathrm{Pt} / \mathrm{CFC}$ and $\mathrm{Ag} / \mathrm{AgCl} / \mathrm{CFC}$ should be stored at $60^{\circ} \mathrm{C}$ in a constant temperature dryer after washing with pure water and the subsequent drying procedure.

\subsection{Preparation of the Flexible Integrated Sensor Device}

As shown in Figure S3, the original blank electrodes used here are flexible carbon fiber cloth, including the working electrode with a size of $30 \mathrm{~mm} \times 5 \mathrm{~mm}$ and leaving a $5 \mathrm{~mm} \times 5 \mathrm{~mm}$ area to load the nanocomposites $\left(\mathrm{Au} @ \mathrm{Cu}(\mathrm{OH})_{2}\right)$, the reference electrode with a size of $30 \mathrm{~mm} \times 2.5 \mathrm{~mm}$ and leaving a $5 \mathrm{~mm} \times 2.5 \mathrm{~mm}$ area to be loaded with $\mathrm{Ag} / \mathrm{AgCl}$ and the counter electrode in a seven formation with a size of $32 \mathrm{~mm} \times 2.5 \mathrm{~mm}$ as well as $9.5 \mathrm{~mm} \times 2.5 \mathrm{~mm}$ and leaving $5 \mathrm{~mm} \times 2.5 \mathrm{~mm}$ as well as a $5 \mathrm{~mm} \times 2.5 \mathrm{~mm}$ area to be plated with Pt. After the three electrodes are fabricated, they are assembled on a poly-tetra prone (PTFE) film with a size of $40 \mathrm{~mm} \times 20 \mathrm{~mm}$ at equal intervals of $2 \mathrm{~mm}$. Then, another PTFE film with special openings (load material area of three electrodes) is laminated on it with nano-double-sided tape. In this way, a flexible micro-glucose sensor is obtained, the optical images of which can be seen in Figure S4.

\subsection{Characterizations and Electrochemical Measurement}

The surface morphologies of the electrodes were examined by Field Emission Scanning Electron Microscopy (SEM, Hitachi, SU8010, $10 \mathrm{keV}$ ) equipped with an energy dispersive spectrometer (EDS, IXRF). X-ray diffraction (XRD, Rigaku D-MAX 2200 VPC, Cu-K $\alpha$ ) was used to characterize the crystal structure of each sample. X-ray photoelectron spectroscopy (XPS) was collected with K-ALPHA ${ }^{+}$ spectroscopy using a monochromatic $\mathrm{Al} \mathrm{K} \alpha \mathrm{X}$-ray source (1486.6 eV photons). Chronoamperometry (CA), linear sweep voltammetry (LSV), cyclic voltammetry (CV) and electrochemical impedance spectroscopy (EIS) were performed by Gamry Reference 600. In addition, all electrochemical tests were made in the three-electrode integrated system, in which the $\mathrm{Au} @ \mathrm{Cu}(\mathrm{OH})_{2} / \mathrm{CFC}, \mathrm{Cu}(\mathrm{OH})_{2} / \mathrm{CFC}$, $\mathrm{Au} / \mathrm{CFC}$ and CFC electrodes prepared on the device were used as working electrodes, respectively. The as-prepared Pt electrode and $\mathrm{Ag} / \mathrm{AgCl} / \mathrm{CFC}$ electrode were, respectively, the counter electrode and reference electrode. It should be noted that in electrochemical tests, the area outside the working portion of the three electrodes is covered with Teflon tape to prevent the device from being damaged by the test solution. The volume of different solutions (with $0.01 \mathrm{M} \mathrm{KCl}$ inside to maintain the stability of the reference electrode) for all electrochemical tests are $50 \mathrm{~mL}$ and the components of each test solution were presented in the corresponding test section. In this paper all potentials were referenced to an as-prepared $\mathrm{Ag} / \mathrm{AgCl} / \mathrm{CFC}$ electrode and all $\mathrm{LSV}$ test potentials range from $-0.3 \mathrm{~V}$ to $0.8 \mathrm{~V}$ unless otherwise stated. Besides this, all the CA tests were carried out with a continuous stirring of $200 \mathrm{rpm}$ to allow the analyte to diffuse rapidly.

\section{Results and Discussion}

\subsection{Characterizations of the $\mathrm{Au} @ \mathrm{Cu}(\mathrm{OH})_{2} / \mathrm{CFC}$ Sensor}

Figure $2 \mathrm{~A}, \mathrm{~B}$ shows the SEM images of pre-treated carbon fiber cloth and $\mathrm{Cu} / \mathrm{CFC}$, respectively. Obviously, the copper film is plated on CFC successfully and the deposited copper is a layer of coarse copper particles, which can greatly increase the contact area between the copper film and the electrolyte solution. $\mathrm{Cu}(\mathrm{OH})_{2}$ arrays with a diameter about $100-280 \mathrm{~nm}$ and length of $1.5-2.0 \mu \mathrm{m}$ show grass-like morphology on the surface of CFC (Figure 2C), which was converted from $\mathrm{Cu} / \mathrm{CFC}$ by repeatedly scanning with LSV. The grass morphology structure significantly increased the space of $\mathrm{Cu}(\mathrm{OH})_{2} / \mathrm{CFC}$ and the possibility of providing more active sites [39]. Subsequently, $\mathrm{Cu}(\mathrm{OH})_{2} / \mathrm{CFC}$ was decorated with a tiny amount of Au nanoparticles by chronoamperometry (Figure 2D). Even after deposition of $\mathrm{Au}$, the final $\mathrm{Au} @ \mathrm{Cu}(\mathrm{OH})_{2} / \mathrm{CFC}$ electrode still exhibits well-defined nanograss structure and the $\mathrm{Au}$ nanoparticles are distributed in the middle and lower parts of $\mathrm{Cu}(\mathrm{OH})_{2}$ nanograss, as seen from the inset of Figure 2D. As seen from Figure S5, both the obtained $\mathrm{Pt} / \mathrm{CFC}$ and $\mathrm{Ag} / \mathrm{AgCl} / \mathrm{CFC}$ have a rough but very uniform structure. 


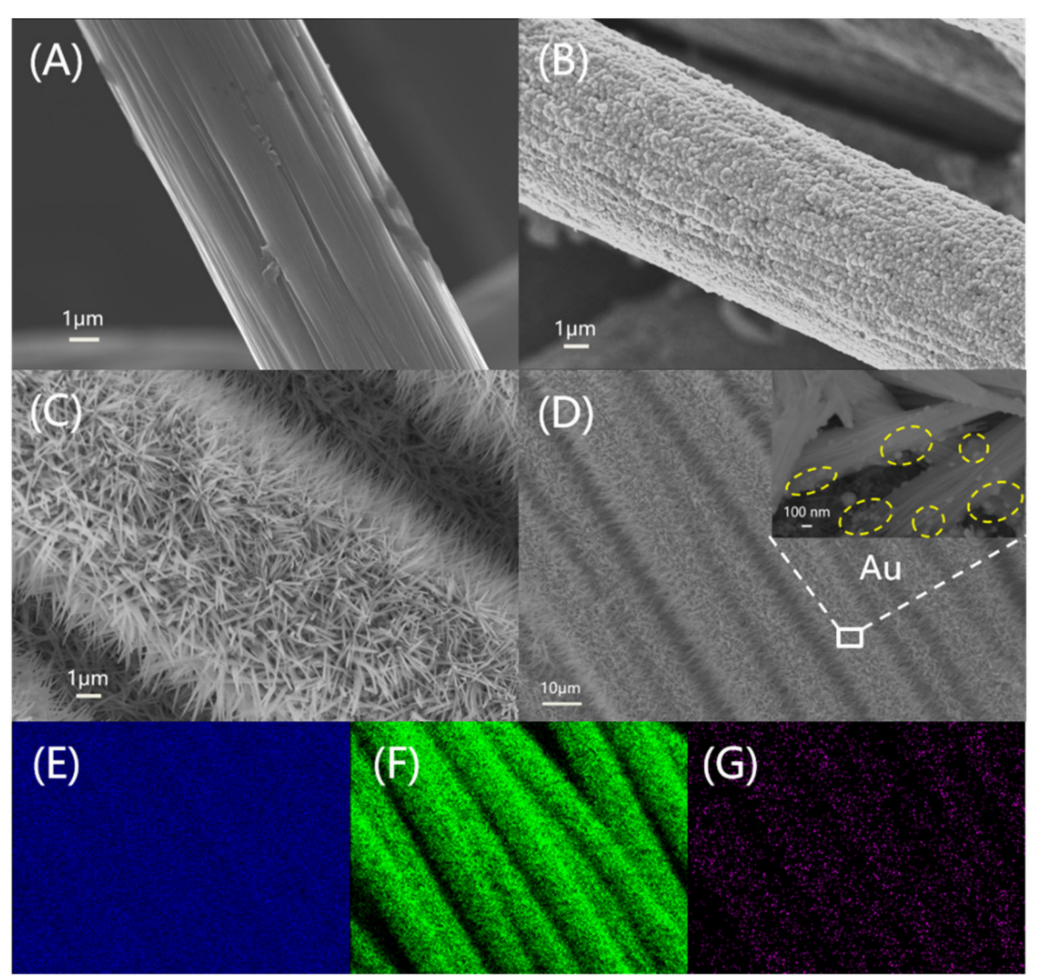

Figure 2. High-magnification SEM images of (A) CFC, (B) $\mathrm{Cu} / \mathrm{CFC}$ and $(\mathbf{C}) \mathrm{Cu}(\mathrm{OH})_{2} / \mathrm{CFC}$, (D) Lowmagnification SEM image of $\mathrm{Au} @ \mathrm{Cu}(\mathrm{OH})_{2} / \mathrm{CFC}$ (Inset is the partial enlarged view), EDX elemental mapping images of (E) $\mathrm{Cu},(\mathbf{F}) \mathrm{O}$ and $(\mathbf{G})$ Au corresponding to (D).

To further ascertain the detailed composition and the crystal structure of the synthesized materials, EDS, XRD and XPS were performed. EDS element mapping images in Figure 2E-G demonstrate a uniform distribution of $\mathrm{Cu}, \mathrm{O}$ and $\mathrm{Au}$ elements on the $\mathrm{Au} @ \mathrm{Cu}(\mathrm{OH})_{2} / \mathrm{CFC}$. Figure $\mathrm{S} 6 \mathrm{~A}, \mathrm{~B}$ presents the typical EDS spectrums of $\mathrm{Cu} / \mathrm{CFC}$ and $\mathrm{Au} @ \mathrm{Cu}(\mathrm{OH})_{2} / \mathrm{CFC}$, with the core element compositions listed as insets. It is obvious that the atomic ratio of $\mathrm{Cu}$ to $\mathrm{O}$ elements is changed from about 22:5 (Figure S6A) to about 7:10 (Figure S6B), indicating a significant oxidation process on the $\mathrm{Cu} / \mathrm{CFC}$. Moreover, the $\mathrm{Au}$ element with an atom content of $4.30 \%$ (Figure S6B) verifies the presence of $\mathrm{Au}$ on the electrode surface. It is worth adding that the signal of $C$ is mainly from the substrate (CFC).

To avoid strong signal interference from the CFC substrate, a copper plate was chosen instead of it to be the substrate of $\mathrm{Au} @ \mathrm{Cu}(\mathrm{OH})_{2}$ for the XRD test. The XRD pattern of the $\mathrm{Au} @ \mathrm{Cu}(\mathrm{OH})_{2} / \mathrm{Cu}$ plate is recorded in Figure S6C, which is magnified in Figure S6D to interpret its plate pattern in a better manner. As shown in Figure S6D, there are seven diffraction peaks in the $\mathrm{Au} @ \mathrm{Cu}(\mathrm{OH})_{2} / \mathrm{Cu}$ plate at $16.7^{\circ}, 23.8^{\circ}, 34.1^{\circ}, 35.8^{\circ}, 38.0^{\circ}, 39.8^{\circ}$ and $53.2^{\circ}$ corresponding to the (020), (021), (002), (011), (041), (130) and (150) crystal planes of $\mathrm{Cu}(\mathrm{OH})_{2}$ (JCPDS NO. 80-0656), respectively. The peaks at $38.2^{\circ}$, $44.5^{\circ}$ and $64.7^{\circ}$ correspond to the (111), (200) and (220) crystal planes of the cubic form of Au (JCPDS NO. 65-8601), respectively. Moreover, the three major peaks at $43.3^{\circ}, 50.4^{\circ}$ and $74.1^{\circ}$ correspond to the (111), (200) and (220) crystal planes of Cu (JCPDS NO. 04-0836), respectively. To further confirm the material composition of the $\mathrm{Au} @ \mathrm{Cu}(\mathrm{OH})_{2} / \mathrm{CFC}$, the XPS analysis was conducted. As shown in the full spectrum survey in Figure $3 \mathrm{~A}$, the $\mathrm{Cu}, \mathrm{O}, \mathrm{C}$ and $\mathrm{Au}$ elements exist in this sample. As shown in Figure 3B, the two peaks at 954.21 and $934.27 \mathrm{eV}$ correspond to the $\mathrm{Cu} 2 \mathrm{p}_{1 / 2}$ and $\mathrm{Cu} 2 \mathrm{p}_{3 / 2}$ of the oxidized $\mathrm{Cu}$ (II) species, respectively, and the satellite peaks indicate the presence of high-spin $\mathrm{Cu}$ (II) ions [40]. It can be inferred that these $\mathrm{Cu} 2 \mathrm{p}$ peaks are consistent with $\mathrm{Cu}(\mathrm{OH})_{2}$ [41,42]. Figure $3 \mathrm{C}$ is the high-resolution XPS spectra of $\mathrm{O} 1 \mathrm{~s}$, in which a well-resolved $\mathrm{O} 1 \mathrm{~s}$ peak is observed at $532.06 \mathrm{eV}$ that further confirms the existence of $\mathrm{Cu}(\mathrm{OH})_{2}$ [43]. In addition, the binding energies of the doublet for $\mathrm{Au} 4 \mathrm{f}_{7 / 2}(83.84 \mathrm{eV})$ and $\mathrm{Au} 4 \mathrm{f}_{5 / 2}(87.48 \mathrm{eV})$ shown in Figure 3D are characteristic of $\mathrm{Au}(0)$ [44], which affirms that Au nanoparticles are decorated on the electrode as a pure element. 

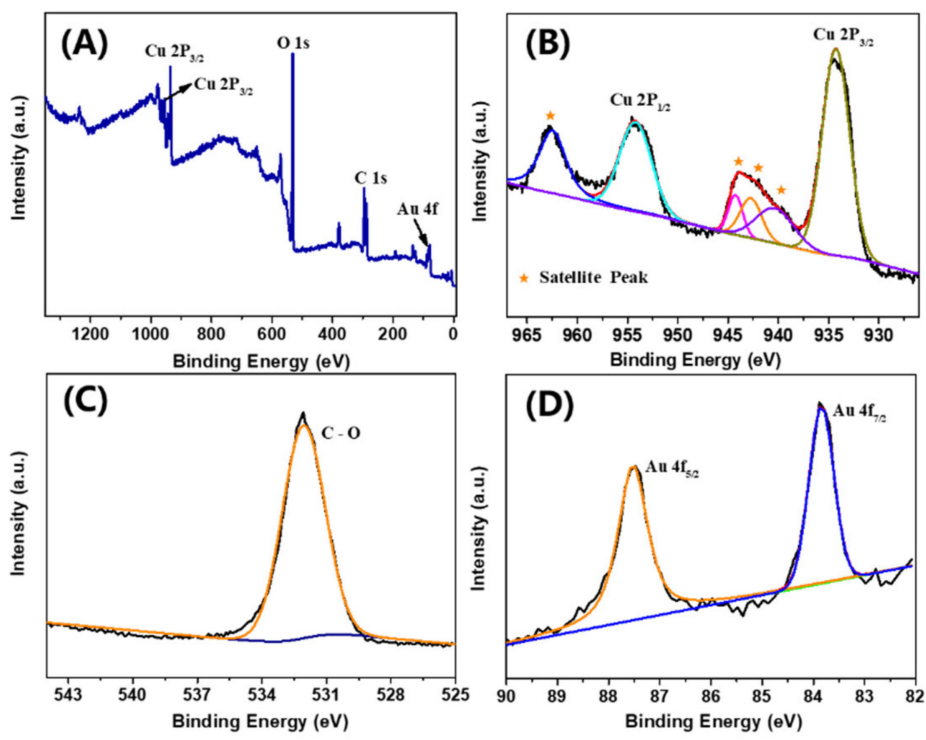

Figure 3. XPS spectra of $\mathrm{Au} @ \mathrm{Cu}(\mathrm{OH})_{2} / \mathrm{CFC}$; (A) full spectrum survey; (B) Cu 2P; (C) O 1s; (D) Au 4 f.

\subsection{Mechanism of Electrode Fabrication and Glucose Oxidation}

Figure S7A presents the LSV curves of fabricating $\mathrm{Cu}(\mathrm{OH})_{2} / \mathrm{CFC}$ electrodes. In the present conditions, the surface of the copper film is free of oxide at potentials negative of about $-0.4 \mathrm{~V}$ and no $\mathrm{Cu}(\mathrm{III})$ species produce [45]. Obviously, there exist two anode peaks at around $-112 \mathrm{mV}$ (peak A) and $80 \mathrm{mV}$ (peak B), which correspond to the oxidation processes of $\mathrm{Cu}$ to $\mathrm{Cu}(\mathrm{I})$ and $\mathrm{Cu}(\mathrm{I})$ to $\mathrm{Cu}(\mathrm{II})$, respectively $[33,46]$. The strength of both peaks drops sharply on the second and the third LSV curves, indicating that the conversions of copper to oxide are basically completed. The corresponding mechanism can be explained as follows:

$$
\begin{gathered}
\text { Peak } \mathrm{A}: \mathrm{Cu}+\mathrm{OH}^{-} \rightarrow \mathrm{CuOH}+\mathrm{e}^{-} \\
2 \mathrm{CuOH} \leftrightarrow \mathrm{Cu}_{2} \mathrm{O}+\mathrm{H}_{2} \mathrm{O} \\
\text { Peak B : } \mathrm{CuOH}+\mathrm{OH}^{-} \rightarrow \mathrm{Cu}(\mathrm{OH})_{2}+\mathrm{e}^{-} \\
\mathrm{Cu}_{2} \mathrm{O}+2 \mathrm{OH}^{-}+\mathrm{H}_{2} \mathrm{O} \rightarrow 2 \mathrm{Cu}(\mathrm{OH})_{2}+2 \mathrm{e}^{-}
\end{gathered}
$$

The electrocatalytic activity of the composite material was first studied by the LSV. Figure S7B presents the LSV curves of the $\mathrm{Cu}(\mathrm{OH})_{2} / \mathrm{CFC}$ and $\mathrm{Au} @ \mathrm{Cu}(\mathrm{OH})_{2} / \mathrm{CFC}$ sensor devices in a $0.1 \mathrm{M} \mathrm{KOH}$ solution without and with $1 \mathrm{mM}$ glucose, respectively. In the presence of glucose, a well-defined anodic peak appears at the potential of near $0.6 \mathrm{~V}$ for both $\mathrm{Cu}(\mathrm{OH})_{2} / \mathrm{CFC}$ and $\mathrm{Au} @ \mathrm{Cu}(\mathrm{OH})_{2} / \mathrm{CFC}$ devices, indicating an obvious process of glucose oxidation [47]. The LSV curves of $\mathrm{Au} @ \mathrm{Cu}(\mathrm{OH})_{2} / \mathrm{CFC}$, $\mathrm{Cu}(\mathrm{OH})_{2} / \mathrm{CFC}, \mathrm{Au} / \mathrm{CFC}$ and CFC devices in $0.1 \mathrm{M} \mathrm{KOH}$ with $1 \mathrm{mM}$ glucose are shown in Figure 4A; $\mathrm{Cu}(\mathrm{OH})_{2} / \mathrm{CFC}$ shows a strong response to glucose and has a distinct anodic peak, indicating the effective catalytic activity of $\mathrm{Cu}(\mathrm{OH})_{2}$. Similarly, $\mathrm{Au} @ \mathrm{Cu}(\mathrm{OH})_{2} / \mathrm{CFC}$ shows a stronger response starting from around $0.2 \mathrm{~V}$. Moreover, there is an anodic peak in $\mathrm{Au} / \mathrm{CFC}$ at around $0.5 \mathrm{~V}$, consistent with our previous study that nanoporous Au catalyzes glucose in the around range of 0.2 to $0.52 \mathrm{~V}$ [38]. In order to further study the role of gold nanoparticles in nanocomposites, the electrochemically active surface areas (ECSA) and the impedances of the composite electrodes were measured.

ECSA proportional to the double layer capacitance $\left(C_{d l}\right)$ is usually used to evaluate the active sites of the electrocatalyst $[48,49]$. Herein, the $C_{d l}$ was obtained by the CV method (Figure S8A,B) in $0.1 \mathrm{M} \mathrm{KOH}$ at various scan rates $\left(10-50 \mathrm{mV} \mathrm{s}^{-1}\right)$ with the corresponding cyclic voltammograms -0.20 to $-0.10 \mathrm{~V}$ where the current changes are due to the charges of the double layer [50]. Figure S8C shows the linearly fitted relationships between $\Delta j_{-0.15 \mathrm{~V}}$ and $v$ of $\mathrm{Cu}(\mathrm{OH})_{2} / \mathrm{CFC}$ and $\mathrm{Au} @ \mathrm{Cu}(\mathrm{OH})_{2} / \mathrm{CFC}$. Obviously, the $C_{d l}$ of $\mathrm{Au} @ \mathrm{Cu}(\mathrm{OH})_{2} / \mathrm{CFC}\left(1.0804 \mathrm{mF} \mathrm{cm}^{-2}\right)$ is much larger than that of $\mathrm{Cu}(\mathrm{OH})_{2} / \mathrm{CFC}$ 
$\left(0.4339 \mathrm{mF} \mathrm{cm}^{-2}\right)$, which suggests the higher ECSA of $\mathrm{Au} @ \mathrm{Cu}(\mathrm{OH})_{2} / \mathrm{CFC}$ and further demonstrates that the Au nanoparticles greatly help increasing the catalytic active sites $[48,50]$. Figure S8D shows the Nyquist plots of $\mathrm{Cu}(\mathrm{OH})_{2} / \mathrm{CFC}$ and $\mathrm{Au} @ \mathrm{Cu}(\mathrm{OH})_{2} / \mathrm{CFC}$ electrodes in the frequency range from $10^{-1}$ to $10^{5} \mathrm{~Hz}$ and the measurement was conducted in $5 \mathrm{mM} \mathrm{K}_{3}\left[\mathrm{Fe}(\mathrm{CN})_{6}\right] / \mathrm{K}_{4}\left[\mathrm{Fe}(\mathrm{CN})_{6}\right]$ with a $0.1 \mathrm{M} \mathrm{KCl}$ supporting electrolyte. It can be found that both Nyquist plots consist of a semicircle portion at high frequencies and a linear portion at low frequency ranges that correspond to the electron-transfer limited and diffusion limited processes, respectively [51]. The inset represents the equivalent Randle circuit for the two cases and the Rct (charge-transfer resistance) of the $\mathrm{Au} @ \mathrm{Cu}(\mathrm{OH})_{2} / \mathrm{CFC}\left(\mathrm{Rct}=12.03 \Omega \mathrm{cm}^{2}\right)$ is found to be much lower than that of the $\mathrm{Cu}(\mathrm{OH})_{2} / \mathrm{CFC}\left(\mathrm{Rct}=27.72 \Omega \mathrm{cm}^{2}\right)$. This indicates that the modification of Au can significantly enhance the charge transfer ability of the electrode during the electrocatalytic process [52].

Above all, the electrocatalytic process for glucose oxidation on the $\mathrm{Au} @ \mathrm{Cu}(\mathrm{OH})_{2} / \mathrm{CFC}$ electrode is mediated by the $\mathrm{Cu}(\mathrm{II}) / \mathrm{Cu}(\mathrm{III})$ and $\mathrm{Au}(0) / \mathrm{Au}(\mathrm{I})$ redox couples, as expressed in Equations (5)-(8) $[31,38,53]$. During anodic scan in an alkaline medium, the $\mathrm{Cu}(\mathrm{OH})_{2}$ and $\mathrm{Au}$ are first electrooxidized to $\mathrm{CuOOH}$ and $\mathrm{Au}(\mathrm{OH})_{\text {ads }}$ active intermediates. Then they could oxidize glucose to gluconic acid after the addition of glucose.

$$
\begin{gathered}
\mathrm{Cu}(\mathrm{OH})_{2}+\mathrm{OH}^{-} \rightarrow \mathrm{CuOOH}+\mathrm{e}^{-}+\mathrm{H}_{2} \mathrm{O} \\
\mathrm{Au}+\mathrm{OH}^{-} \rightarrow \mathrm{Au}(\mathrm{OH})_{\text {ads }}+\mathrm{e}^{-} \\
2 \mathrm{CuOOH}+\mathrm{C}_{6} \mathrm{H}_{12} \mathrm{O}_{6}(\text { Glucose })+\mathrm{H}_{2} \mathrm{O} \rightarrow \mathrm{C}_{6} \mathrm{H}_{12} \mathrm{O}_{7} \text { (Glucose acid) }+2 \mathrm{Cu}(\mathrm{OH})_{2} \\
2 \mathrm{Au}(\mathrm{OH})_{\mathrm{ads}}+\mathrm{C}_{6} \mathrm{H}_{12} \mathrm{O}_{6} \text { (Glucose) } \rightarrow \mathrm{C}_{6} \mathrm{H}_{12} \mathrm{O}_{7} \text { (Glucoseacid) }+2 \mathrm{Au}+\mathrm{H}_{2} \mathrm{O}
\end{gathered}
$$

\subsection{Non-Enzymatic Glucose Electrochemical Performance of an $\mathrm{Au} @ \mathrm{Cu}(\mathrm{OH})_{2} / \mathrm{CFC}$ Sensor}

Figure $4 \mathrm{~B}$ displays the LSV curves of the $\mathrm{Au} @ \mathrm{Cu}(\mathrm{OH})_{2} / \mathrm{CFC}$ in $0.1 \mathrm{M} \mathrm{KOH}$ with different concentrations of glucose (ranging from 0 to $3.0 \mathrm{mM}$ ) at a scan rate of $50 \mathrm{mV} \mathrm{s}^{-1}$. The response current enhances obviously following the increase of the glucose concentration, which indicates a good catalytic effect of $\mathrm{Au} @ \mathrm{Cu}(\mathrm{OH})_{2} / \mathrm{CFC}$ towards glucose [54]. The LSV curves of $\mathrm{Au} @ \mathrm{Cu}(\mathrm{OH})_{2} / \mathrm{CFC}$ in $0.1 \mathrm{M} \mathrm{KOH}$ with $1 \mathrm{mM}$ glucose at different scan rates (from 5 to $110 \mathrm{mV} \mathrm{s}^{-1}$ ) are depicted in Figure 4C. Obviously, the anodic peak current increases as the scan rates increases. In addition, the oxidation peak current density $j\left(\mathrm{~mA} \mathrm{~cm}^{-2}\right)$ against square root of scan rate $v\left(\mathrm{mV} \mathrm{s}^{-1}\right)$ shows a brilliant linear relationship (Figure 4D) which can be expressed as: $j=0.4966^{*} v^{1 / 2}+0.3171\left(\mathrm{R}^{2}=0.9958\right)$. The relationship suggests that the electrochemical behavior of glucose oxidation on $\mathrm{Au} @ \mathrm{Cu}(\mathrm{OH})_{2} / \mathrm{CFC}$ is controlled by a diffusion process.

As can be seen from Equations (5) and (6), the $\mathrm{OH}^{-}$plays an important role in the catalytic oxidation of glucose. Therefore, different concentrations of $\mathrm{KOH}$ solutions (ranging from 0.01 to $1.00 \mathrm{M}$ ) were researched by $\mathrm{CA}$ tests with the addition of $0.1 \mathrm{mM}$ glucose at $0.60 \mathrm{~V}$ to optimize the sensing performance of the $\mathrm{Au} @ \mathrm{Cu}(\mathrm{OH})_{2} / \mathrm{CFC}$ (Figure S9A). The results demonstrate that the optimal concentration of $\mathrm{KOH}$ is $0.1 \mathrm{M}$. After a similar screening experiment, the optimized test potential for the CA tests is determined to be $0.60 \mathrm{~V}$ (Figure S9B). Hence, a $0.10 \mathrm{M} \mathrm{KOH}$ solution and $0.60 \mathrm{~V}$ are selected as the optimal electrolyte and test potential, respectively, for all the subsequent CA tests.

Figure 5A presents the chronoamperometric response curve of an $\mathrm{Au} @ \mathrm{Cu}(\mathrm{OH})_{2} / \mathrm{CFC}$ sensor towards the successive addition of glucose. For ease of observation, the current response curve of $\mathrm{Au} @ \mathrm{Cu}(\mathrm{OH})_{2} / \mathrm{CFC}$ to low concentrations of glucose is inserted in Figure 5A. It can be easily found that an $\mathrm{Au} @ \mathrm{Cu}(\mathrm{OH})_{2} / \mathrm{CFC}$ sensor device has a current response sensitive to glucose even diluted to $0.1 \mu \mathrm{M}$, and the current response exhibits a linear relationship towards the addition of glucose (Figure 5B). In order to explore the exact upper limit of the linear range, the chronoamperometric response of $\mathrm{Au} @ \mathrm{Cu}(\mathrm{OH})_{2} / \mathrm{CFC}$ towards the successive additions of $0.1 \mathrm{mM}$ glucose was measured (Figure 5C). As shown in Figure 5D, the current response is linearly enhanced up to $3.3 \mathrm{mM}$; after that, the enhancement of the current response is gradually weakened. The linear relationship between the 
current density $j\left(\mathrm{~mA} \mathrm{~cm}^{-2}\right)$ and the corresponding glucose concentration $c(\mathrm{mM})$ can be calculated by the equation: $j=7.5983 c+0.0896$ with correlation coefficients of 0.9974 . Therefore, the sensitivity of the Au@Cu(OH $)_{2} / \mathrm{CFC}$ electrode towards glucose detection is $7.5983 \mathrm{~mA} \mathrm{mM}^{-1} \mathrm{~cm}^{-2}$ and the limit of detection (LOD) can be calculated to be $26.97 \mathrm{nM}(\mathrm{S} / \mathrm{N}=3)$ by the criteria formula of $\mathrm{LOD}=3 \delta_{b} / \mathrm{m}$, where $\delta_{b}$ is the standard deviation $\left(7.15 \times 10^{-5} \mathrm{~mA} \mathrm{~cm}^{-2}\right)$ of the blank sample and $m$ is the sensitivity of the electrode [51].

(A)
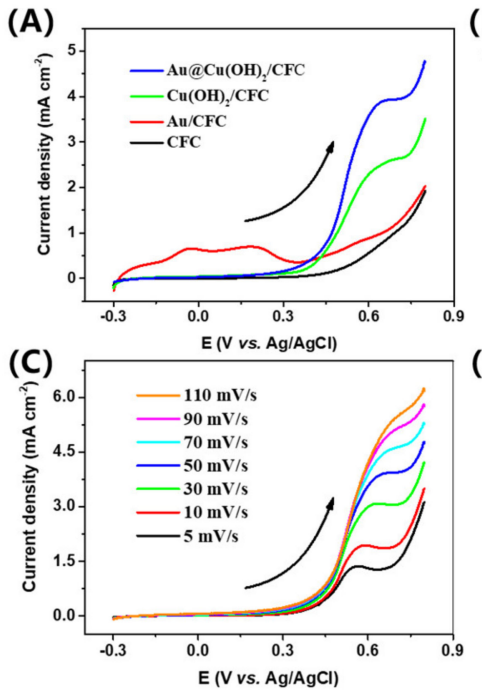

(B) 15
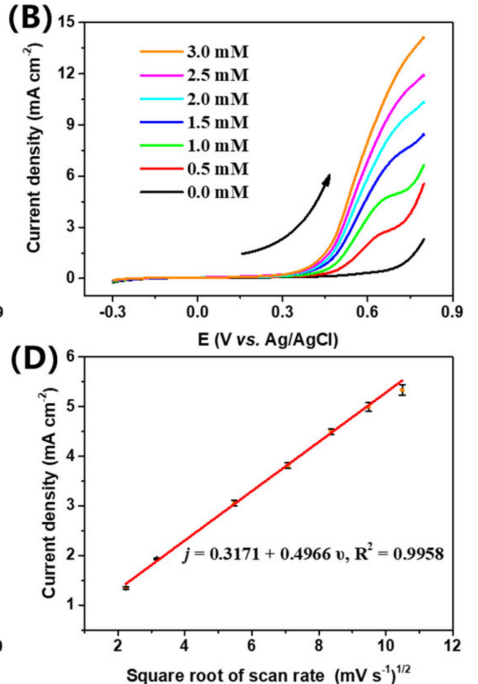

Figure 4. (A) Linear sweep voltammetry (LSV) curves of the bare $\mathrm{CFC}, \mathrm{Au} / \mathrm{CFC}, \mathrm{Cu}(\mathrm{OH})_{2} / \mathrm{CFC}$, $\mathrm{Au} @ \mathrm{Cu}(\mathrm{OH})_{2} / \mathrm{CFC}$ at a scan of $50 \mathrm{mV} \mathrm{s}^{-1}$ in $0.1 \mathrm{M} \mathrm{KOH}$ with $1.0 \mathrm{mM}$ glucose. (B) LSV curves of $\mathrm{Au} @ \mathrm{Cu}(\mathrm{OH})_{2} / \mathrm{CFC}$ at different glucose concentrations (from $0.5 \mathrm{mM}$ to $3.0 \mathrm{mM}$ ). (C) LSV curves of $\mathrm{Au} @ \mathrm{Cu}(\mathrm{OH})_{2} / \mathrm{CFC}$ at a scan rate of $5-110 \mathrm{mV} \mathrm{s}^{-1}$ in $0.1 \mathrm{M} \mathrm{KOH}$ with $1.0 \mathrm{mM}$ glucose. (D) Relationship between square scan rate and the anodic peak currents, among which the maximum relative standard deviation (RSD) is $2.04 \%$. The arrows along the LSV curves represent the direction of scanning.
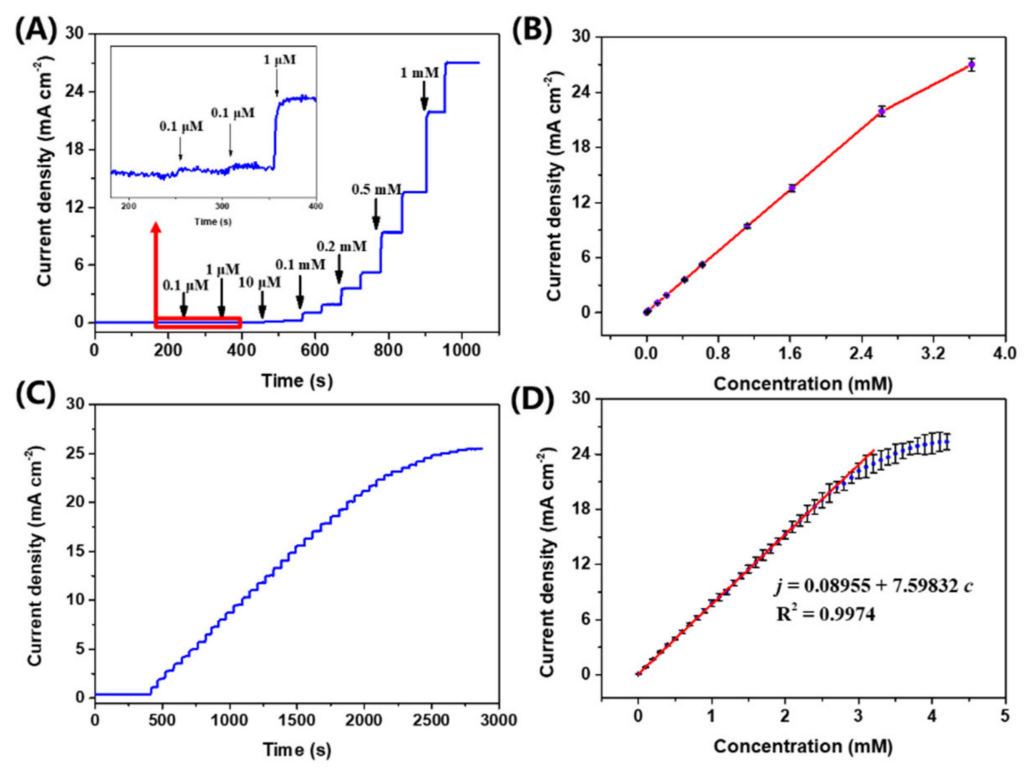

Figure 5. (A) Chronoamperometric response of $\mathrm{Au} @ \mathrm{Cu}(\mathrm{OH})_{2} / \mathrm{CFC}$ towards the successive additions of different concentrations of glucose. (B) The corresponding calibration curve of Figure A. (C) Chronoamperometric response of $\mathrm{Au} @ \mathrm{Cu}(\mathrm{OH})_{2} / \mathrm{CFC}$ towards the successive additions of $0.1 \mathrm{mM}$ glucose. (D) The calibration curve for chronoamperometric response to glucose concentration in the high concentration range (corresponding to Figure C), among which the maximum RSD is $5.1 \%$. 
Table S1 lists the glucose catalytic performances of the $\mathrm{Au} @ \mathrm{Cu}(\mathrm{OH})_{2} / \mathrm{CFC}$ sensor device and some other composites materials. Obviously, compared to the commonly used non-electrochemical methods for detecting glucose, the $\mathrm{Au} @ \mathrm{Cu}(\mathrm{OH})_{2} / \mathrm{CFC}$ sensor has the advantages of better sensitivity, faster response and being more economical. Furthermore, our device also shows much better sensitivity and a lower detection limit in comparison to these similar electrocatalyst materials. Thus, it is a promising candidate for the application of the three-electrode integrated device structure and $\mathrm{Au} @ \mathrm{Cu}(\mathrm{OH})_{2} / \mathrm{CFC}$ nanocomposite on glucose detection.

\subsection{Selectivity, Stability and Reproducibility of the $\mathrm{Au} @ \mathrm{Cu}(\mathrm{OH})_{2} / \mathrm{CFC}$ Sensor}

Selectivity is also a significant indicator of $\mathrm{Au} @ \mathrm{Cu}(\mathrm{OH})_{2} / \mathrm{CFC}$ for glucose detection. Hence, various conventional organic and inorganic ions were selected for an anti-interference test of $\mathrm{Au} @ \mathrm{Cu}(\mathrm{OH})_{2} / \mathrm{CFC}$ for glucose detection. The general glucose concentration in humans is fairly higher than that of the coexisting interferences such as maltose, fructose, UA, DA, AA, Cys and 4-AP [15], so the concentration of each interference $(0.01 \mathrm{mM})$ was selected to be one tenth of the glucose concentration $(0.1 \mathrm{mM})$ for the anti-interference test (Figure $6 \mathrm{~A})$. In addition, high concentrations $(1.00 \mathrm{mM})$ of $\mathrm{KCl}$ and $\mathrm{Na}_{2} \mathrm{SO}_{4}$ were added to determine the anti-interference ability of $\mathrm{Au} @ \mathrm{Cu}(\mathrm{OH})_{2} / \mathrm{CFC}$ to conventional inorganic ions. As the results show in Table S2, the signals of organic interferences are less than $4 \%$, and the response signal to inorganic substances is smaller (less to $2 \%$ ). This test demonstrates that the $\mathrm{Au} @ \mathrm{Cu}(\mathrm{OH})_{2} / \mathrm{CFC}$ is highly selective for glucose detection and is almost unaffected by conventional inorganic ions $\left(\mathrm{K}^{+}\right.$, $\left.\mathrm{Na}^{+}, \mathrm{Cl}^{-}\right)$. Figure $6 \mathrm{~B}$ presents the continuous chronoamperometric response of $\mathrm{Au} @ \mathrm{Cu}(\mathrm{OH})_{2} / \mathrm{CFC}$ towards $0.1 \mathrm{M}$ glucose to measure the long-term operation ability of the electrode for glucose detection. The result expounds that $\mathrm{Au} @ \mathrm{Cu}(\mathrm{OH})_{2} / \mathrm{CFC}$ can keep a stable current response for over $3000 \mathrm{~s}$ with only $6.28 \%$ decay. Moreover, the same $\mathrm{Au} @ \mathrm{Cu}(\mathrm{OH})_{2} / \mathrm{CFC}$ sensor was tested in the same concentration of glucose solution at the same time every two days and it could keep with a stable performance for nine days, as demonstrated in the inset of Figure 6B. Thus, our $\mathrm{Au} @ \mathrm{Cu}(\mathrm{OH})_{2} / \mathrm{CFC}$ glucose sensor has potential in practical applications with stable performance. The folded stability of the flexible device was further tested. As presented in Figure 6C, it shows nearly no change in the response to glucose after 1000 folded cycles, demonstrating the excellent flexible capacity of the obtained sensor. Five pieces of the $\mathrm{Au} @ \mathrm{Cu}(\mathrm{OH})_{2} / \mathrm{CFC}$ sensor were fabricated using the same preparation process and their chronoamperometric responses towards $0.1 \mathrm{mM}$ glucose are collected in Figure S6D to study the reproducibility. The low relative standard deviation (RSD) of $4.55 \%$ firmly certifies the reliability of the preparation process.

\subsection{Real Sample Analysis}

To evaluate the capability of the $\mathrm{Au} @ \mathrm{Cu}(\mathrm{OH})_{2} / \mathrm{CFC}$ sensor for practical determination, the device was used to detect the glucose concentrations of human serum samples and mulberry drink by the standard addition method [55]. Before the test, the mulberry drink was centrifuged at $5000 \mathrm{rpm}$ for $30 \mathrm{~min}$ and then the serum and mulberry juice were separately diluted 500-fold and 50,000-fold with $0.1 \mathrm{M} \mathrm{KOH}$ to reduce the matrix effect [56]. Finally, the glucose concentration of human serum, mulberry drink and the spiked samples (the mulberry drink samples with added known concentrations of glucose) were measured. From the results listed in Table 1, good recoveries from $92.09 \%$ to $97.89 \%$ with low RSDs ( $0.75 \%$ to $1.02 \%)$ are achieved for mulberry juice detection. Besides this, the glucose concentration of human serum samples measured by an $\mathrm{Au} @ \mathrm{Cu}(\mathrm{OH})_{2} / \mathrm{CFC}$ sensor is consistent with the values detected by a blood glucose meter (SANNUO GA-3, Sinocare Inc., Changsha). These results indicate that the $\mathrm{Au} @ \mathrm{Cu}(\mathrm{OH})_{2} / \mathrm{CFC}$ sensor is excellently reliable in actual glucose detection. 

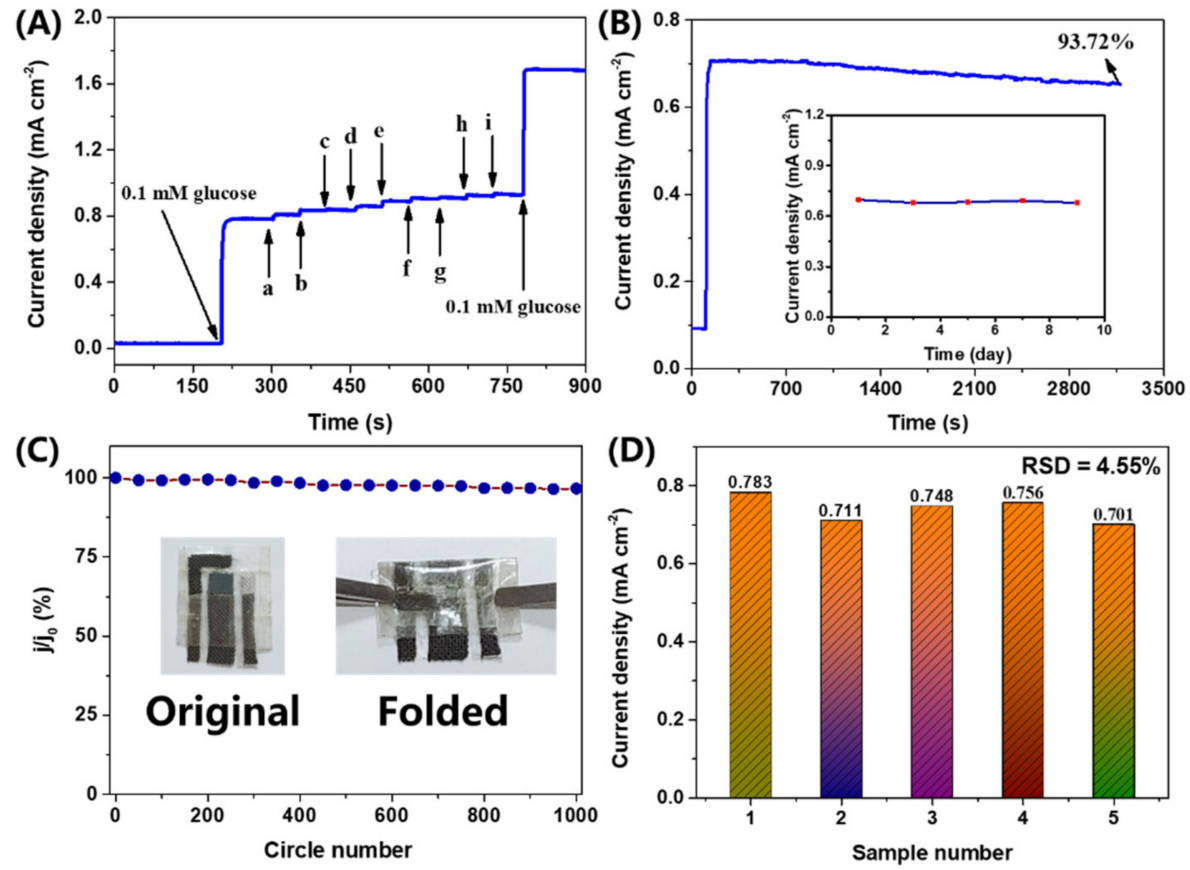

Figure 6. (A) Chronoamperometric response of $\mathrm{Au} @ \mathrm{Cu}(\mathrm{OH})_{2} / \mathrm{CFC}$ sensor toward the addition of $0.1 \mathrm{mM}$ glucose and various interfering species. (a-i are Maltose, Fructose, UA, AA, DA, Cys, 4-AP, KCl and $\mathrm{Na}_{2} \mathrm{SO}_{4}$, respectively). (B) Long-term stability tests of the $\mathrm{Au} @ \mathrm{Cu}(\mathrm{OH})_{2} / \mathrm{CFC}$ sensor in $0.1 \mathrm{M} \mathrm{KOH}$ and $0.01 \mathrm{M} \mathrm{KCl}$ solution containing $0.1 \mathrm{mM}$ glucose for over $3000 \mathrm{~s}$ and 9 days (inset). (C) Folded stability test of the $\mathrm{Au} @ \mathrm{Cu}(\mathrm{OH})_{2} / \mathrm{CFC}$ sensor; inset shows the repeating folded and recovery process ( $\mathrm{j}$ is current response density of the original sensor and $\mathrm{j}_{0}$ is current response density of the folded sensor). (D) The chronoamperometric current response of five pieces $\mathrm{Au} @ \mathrm{Cu}(\mathrm{OH})_{2} / \mathrm{CFC}$ towards $0.1 \mathrm{mM}$ glucose.

Table 1. The detection of glucose concentrations in the human serum sample and mulberry drink.

\begin{tabular}{cccccc}
\hline Samples & $\begin{array}{c}\text { Reference Values } \\
(\mathbf{m M})\end{array}$ & $\begin{array}{c}\text { Added Glucose } \\
(\mathbf{m M})\end{array}$ & $\begin{array}{c}\mathrm{Au} @ \mathbf{C u}(\mathbf{O H})_{2} / \mathrm{CFC}^{\mathrm{c}} \\
(\mathbf{m M})\end{array}$ & $\begin{array}{c}\text { Recovery } \\
\mathbf{( \% )}\end{array}$ & $\begin{array}{c}\text { RSD } \\
(\mathbf{\%}, \mathbf{n}=\mathbf{3})\end{array}$ \\
\hline \multirow{2}{*}{ Mulberry juice } & $670.68^{\mathrm{a}}$ & 400.00 & $1030.83 \pm 8.22$ & 92.09 & 0.75 \\
Human serum & $5.4^{\mathrm{b}}$ & 800.00 & $1439.60 \pm 15.23$ & 97.89 & 1.02 \\
\hline
\end{tabular}

${ }^{a}$ Measured by standard addition method, ${ }^{b}$ measured by blood glucose meter (GA-3), ${ }^{c}$ expressed as "mean value \pm standard deviation".

\section{Conclusions}

In this paper, the flexible $\mathrm{Au} @ \mathrm{Cu}(\mathrm{OH})_{2} / \mathrm{CFC}, \mathrm{Pt} / \mathrm{CFC}$ and $\mathrm{Ag} / \mathrm{AgCl} / \mathrm{CFC}$ electrodes were successfully synthesized by simple electrochemical deposition and oxidation methods. And a flexible three-electrode integrated portable glucose sensor was successfully fabricated, which consists of $\mathrm{Au} @ \mathrm{Cu}(\mathrm{OH})_{2} / \mathrm{CFC}$ as the working electrode, $\mathrm{Pt} / \mathrm{CFC}$ as the counter electrode and $\mathrm{Ag} / \mathrm{AgCl} / \mathrm{CFC}$ as the reference electrode. Due to the following reasons, (I) $\mathrm{Cu}(\mathrm{OH})_{2}$ nanograss arrays possess superior electrochemical catalytic activity for glucose sensing; (II) the modification of the Au nanoparticles accelerates the charge transfer and increases the electrochemically active surface area of the nanograss arrays, providing more catalytic active sites during the electrocatalytic process in an alkaline environment; (III) intimate contact between the active material $\left(\mathrm{Au} @ \mathrm{Cu}(\mathrm{OH})_{2}\right)$ and current collector $(\mathrm{CFC})$ with a macroporous structure supplies good conductivity for electron/ion transport, the sensor exhibited very high sensitivity of $7.35 \mathrm{~mA} \mathrm{mM} \mathrm{mm}^{-1} \mathrm{~cm}^{-2}$, low limit of detection of $26.97 \mathrm{nM}(\mathrm{S} / \mathrm{N}=3)$, superb selectivity and considerable stability towards glucose detection. Additionally, the $\mathrm{Au} @ \mathrm{Cu}(\mathrm{OH})_{2} / \mathrm{CFC}$ flexible portable sensor shows excellent flexible capacity and good reliability in actual glucose detection. All in all, the novel sensor 
can provide a promising structure design for a flexible micro-device and is a great potential material candidate of an electrochemical sensor for glucose sensing.

Supplementary Materials: The following are available online at http://www.mdpi.com/1424-8220/19/22/5055/s1, Figure S1: Optical images of (A) CFC, (B) $\mathrm{Cu} / \mathrm{CFC},(\mathrm{C}) \mathrm{Cu}(\mathrm{OH}) 2 / \mathrm{CFC}$ (D) $\mathrm{Au} @ \mathrm{Cu}(\mathrm{OH}) 2 / \mathrm{CFC}$, Figure S2: Open circuit potential $(\mathrm{OCP})$ between deposited $\mathrm{Ag} / \mathrm{AgCl} / \mathrm{CFC}$ electrode and a commercial $\mathrm{Ag} / \mathrm{AgCl}(3 \mathrm{M} \mathrm{KCl})$ reference electrode in electrolyte solution with $0.1 \mathrm{M} \mathrm{KOH}$ and $0.01 \mathrm{M} \mathrm{KCl}$, Figure S3: Schematic illustration of the fabrication process for the flexible micro glucose sensor, Figure S4: Optical images of the (A) original and (B) folded flexible micro glucose sensor, Figure S5: Low-magnification SEM images of (A) Ag/AgCl/CFC and (B) $\mathrm{Pt} / \mathrm{CFC}$, and High-magnification SEM images of (C) Ag/AgCl/CFC and (D) Pt/CFC, Figure S6: EDS patterns of (A) $\mathrm{Cu} / \mathrm{CFC}$ and $(\mathrm{B}) \mathrm{Au} @ \mathrm{Cu}(\mathrm{OH}) 2 / \mathrm{CFC}, \mathrm{XRD}$ patterns of $(\mathrm{C}) \mathrm{Au} @ \mathrm{Cu}(\mathrm{OH}) 2 / \mathrm{Cu}$ plate and $(\mathrm{D})$ The magnification of (C), Figure S7: LSV curves of $(\mathrm{A})$ fabricating $\mathrm{Cu}(\mathrm{OH}) 2$ samples, from $-0.4 \mathrm{~V}$ to $0.4 \mathrm{~V}$ with $3 \mathrm{mV}$ s -1 sweeping rate in $1 \mathrm{M} \mathrm{KOH}$ resolution for three times, $(\mathrm{B})$ the $\mathrm{Cu}(\mathrm{OH}) 2 / \mathrm{CFC}$ and $\mathrm{Au} @ \mathrm{Cu}(\mathrm{OH}) 2 / \mathrm{CFC}$ sensors in $0.1 \mathrm{M}$ $\mathrm{KOH}$ and $0.01 \mathrm{M} \mathrm{KCl}$ solution without and with $1 \mathrm{mM}$ glucose, Figure S8: CVs for $(\mathrm{A}) \mathrm{Cu}(\mathrm{OH}) 2 / \mathrm{CFC}$ and $(\mathrm{B})$ $\mathrm{Au} @ \mathrm{Cu}(\mathrm{OH}) 2 / \mathrm{CFC}$ sensors with different scan rates( $10-50 \mathrm{mV} \mathrm{s}-1)$ in $0.1 \mathrm{M} \mathrm{KOH}$ and $0.01 \mathrm{M} \mathrm{KCl}$ solution, (C) The capacitive current densities-scan rates calibration plots of the two sensors at $-0.15 \mathrm{~V}(\Delta \mathrm{j}-0.15 \mathrm{~V}=(\mathrm{ja}-$ jc)/2), (D) Nyquist plots of $\mathrm{Cu}(\mathrm{OH}) 2 / \mathrm{CFC}$ and $\mathrm{Au} @ \mathrm{Cu}(\mathrm{OH}) 2 / \mathrm{CFC}$ sensors in $0.1 \mathrm{M} \mathrm{KCl}$ electrolyte with $5 \mathrm{mM}$ $\mathrm{K} 3[\mathrm{Fe}(\mathrm{CN}) 6]$ and $5 \mathrm{mM} \mathrm{K} 4[\mathrm{Fe}(\mathrm{CN}) 6]$, inset is equivalent Randle circuit for the two cases, Figure S9: (A) The line chart of chronoamperometric current response of $\mathrm{Au} @ \mathrm{Cu}(\mathrm{OH}) 2 / \mathrm{CFC}$ towards $0.10 \mathrm{mM}$ glucose in different concentration $\mathrm{KOH}(0.01$ to $1.00 \mathrm{M})$ and $0.01 \mathrm{M} \mathrm{KCl}$ solution at $0.60 \mathrm{~V}$. The maximum RSD is $2.8 \%$. (B) The chronoamperometric current response of $\mathrm{Au} @ \mathrm{Cu}(\mathrm{OH}) 2 / \mathrm{CFC}$ towards $0.10 \mathrm{mM}$ glucose in $0.1 \mathrm{M} \mathrm{KOH}$ and $0.01 \mathrm{M}$ $\mathrm{KCl}$ solution at different potentials (ranging from 0.30 to $0.65 \mathrm{~V}$ ), Table S1: The comparison of glucose sensing performances based on various composites which reported previously. SPE: screen printed electrode, GCE: glassy carbon electrode, rGO: reduced graphene oxide, PGF: porous graphene foam, MWCNTs: multi-walled carbon nanotubes array, Table S2: Table S2. Influence of common interfering species on the determination of glucose with $\mathrm{Au} @ \mathrm{Cu}(\mathrm{OH}) 2 / \mathrm{CFC}$ in $0.1 \mathrm{M} \mathrm{KOH}$ and $0.01 \mathrm{M} \mathrm{KCl}$ solution.

Author Contributions: Methodology, M.J. and G.C.; software, M.J.; validation, J.Z. and G.C.; investigation, M.J.; data curation, M.J.; writing—original draft preparation, M.J.; writing—review and editing, P.S. and L.H.; supervision, J.Z. and G.C.

Funding: This research was funded by National Natural Science Foundation of China, grant number 51271205, 50801070 and 51571093, "Project of Science and Technology Plan" by Qingyuan city (DZXQY052, 2018C005), Project of results transformation achievement fund by Sun Yat-sen University (31000-18843232) and “Tian'e Plan" by Huizhou city $(20170220011822281,20170220085037390)$.

Conflicts of Interest: The authors declare no conflict of interest.

\section{Appendix A}

A detailed description of the open circuit potential test mentioned in Section 2.3.

According to the Nernst equation, the relationship between $E_{\mathrm{Ag} / \mathrm{AgCl}}$ and chloride ions activity $A_{C l}{ }^{-}\left(25^{\circ} \mathrm{C}\right)$ can be described as the equation: $E_{\mathrm{Ag} / \mathrm{AgCl}}(\mathrm{mV})=222-59 \lg A_{\mathrm{Cl}}{ }^{-}$. Generally, $A_{\mathrm{Cl}}{ }^{-}$was replaced by chloride ion concentration $\mathrm{C}_{\mathrm{Cl}}{ }^{-}$for approximate calculation. Thus, the theoretical value of the electric potential difference between the prepared $\mathrm{Ag} / \mathrm{AgCl} / \mathrm{CFC}(0.01 \mathrm{M} \mathrm{KCl})$ and the commercial $\mathrm{Ag} / \mathrm{AgCl}(3 \mathrm{M} \mathrm{KCl})$ reference electrode was calculated to be $146 \mathrm{mV}$, which could be described as the equation: $E_{A g / A g C l}(3 \mathrm{M} \mathrm{KCl}, \mathrm{mV})=E_{A g / A g C l}(0.01 \mathrm{M} \mathrm{KCl})-146$. In order to study the availability of the prepared $\mathrm{Ag} / \mathrm{AgCl} / \mathrm{CFC}$, an open circuit potential (OCP) test was performed in a two-electrode system, in which the obtained $\mathrm{Ag} / \mathrm{AgCl} / \mathrm{CFC}$ worked as the working electrode and the commercial $\mathrm{Ag} / \mathrm{AgCl}$ $(3 \mathrm{M} \mathrm{KCl})$ reference electrode worked as the counter and reference electrode. As seen from Figure $\mathrm{S} 2$, the OCP finally kept steady at $141.6 \mathrm{mV}$ with less than $0.5 \mathrm{mV}$ variation. This result is consistent with the theoretical value, which strongly confirms the availability of the prepared $\mathrm{Ag} / \mathrm{AgCl} / \mathrm{CFC}$ reference electrode.

\section{References}

1. Baghayeri, M.; Amiri, A.; Farhadi, S. Development of non-enzymatic glucose sensor based on efficient loading Ag nanoparticles on functionalized carbon nanotubes. Sens. Actuators B Chem. 2016, 225, 354-362. [CrossRef] 
2. Jia, X.; Dong, S.; Wang, E. Engineering the bioelectrochemical interface using functional nanomaterials and microchip technique toward sensitive and portable electrochemical biosensors. Biosens. Bioelectron. 2016, 76, 80-90. [CrossRef] [PubMed]

3. Chen, H.; Fan, G.; Zhao, J.; Qiu, M.; Sun, P.; Fu, Y.; Han, D.; Cui, G. A portable micro-glucose sensor based on copper-based nanocomposite structure. New J. Chem. 2019, 43, 7806-7813. [CrossRef]

4. Xu, M.; Song, Y.; Ye, Y.; Gong, C.; Shen, Y.; Wang, L.; Wang, L. A novel flexible electrochemical glucose sensor based on gold nanoparticles/polyaniline arrays/carbon cloth electrode. Sens. Actuators B Chem. 2017, 252, 1187-1193. [CrossRef]

5. Chen, C.; Ran, R.; Yang, Z.; Lv, R.; Shen, W.; Kang, F.; Huang, Z. An efficient flexible electrochemical glucose sensor based on carbon nanotubes/carbonized silk fabrics decorated with Pt microspheres. Sens. Actuators $B$ Chem. 2018, 256, 63-70. [CrossRef]

6. Lin, S.; Feng, W.; Miao, X.; Zhang, X.; Chen, S. A flexible and highly sensitive nonenzymatic glucose sensor based on DVD-laser scribed graphene substrate. Biosens. Bioelectron. 2018, 110, 89-96. [CrossRef] [PubMed]

7. Hwa, Y.; Soo, D.; Na, Y.; Kim, H.; Ho, D.; Ahn, S.; Yang, J.; Seok, W.; Seo, S. Flexible glucose sensor using CVD-grown graphene-based field effect transistor. Biosens. Bioelectron. 2012, 37, 82-87.

8. Cheng, Q.; Tang, J.; Ma, J.; Zhang, H.; Shinya, N.; Qin, L. Polyaniline-Coated Electro-Etched Carbon Fiber Cloth Electrodes for Supercapacitors. J. Phys. Chem. C 2011, 115, 23584-23590. [CrossRef]

9. Chen, T.; Li, X.; Qiu, C.; Zhu, W.; Ma, H.; Chen, S.; Meng, O. Electrochemical sensing of glucose by carbon cloth-supported $\mathrm{Co}_{3} \mathrm{O}_{4} / \mathrm{PbO}_{2}$ core-shell nanorod arrays. Biosens. Bioelectron. 2014, 53, 200-206. [CrossRef]

10. Xu, J.; Li, F.; Wang, D.; Hasnain, M.; An, Q.; Han, D. $\mathrm{Co}_{3} \mathrm{O}_{4}$ nanostructures on flexible carbon cloth for crystal plane effect of nonenzymatic electrocatalysis for glucose. Biosens. Bioelectron. 2019, 123, 25-29. [CrossRef]

11. Liu, Q.; Yang, Y.; Li, H.; Zhu, R.; Shao, Q.; Yang, S.; Xu, J. NiO nanoparticles modified with 5,10,15,20tetrakis(4-carboxyl pheyl)-porphyrin: Promising peroxidase mimetics for $\mathrm{H}_{2} \mathrm{O}_{2}$ and glucose detection. Biosens. Bioelectron. 2015, 64, 147-153. [CrossRef]

12. Jiang, X.; Sun, C.; Guo, Y.; Nie, G.; Xu, L. Peroxidase-like activity of apoferritin paired gold clusters for glucose detection. Biosens. Bioelectron. 2015, 64, 165-170. [CrossRef] [PubMed]

13. Rahman, M.M.; Ahammad, A.J.S.; Jin, J.H.; Ahn, S.J.; Lee, J.J. A comprehensive review of glucose biosensors based on nanostructured metal-oxides. Sensors 2010, 10, 4855-4886. [CrossRef] [PubMed]

14. Tian, K.; Prestgard, M.; Tiwari, A. A review of recent advances in nonenzymatic glucose sensors. Mater. Sci. Eng. C 2014, 41, 100-118. [CrossRef] [PubMed]

15. Dong, C.; Zhong, H.; Kou, T.; Frenzel, J.; Eggeler, G.; Zhang, Z. Three-dimensional Cu foam-supported single crystalline mesoporous $\mathrm{Cu}_{2} \mathrm{O}$ nanothorn arrays for ultra-highly sensitive and efficient nonenzymatic detection of glucose. ACS Appl. Mater. Interfaces 2015, 7, 20215-20223. [CrossRef] [PubMed]

16. Sudarsanam, P.; Peeters, E.; Makshina, E.V.; Parvulescu, V.I.; Sels, B.F. Advances in porous and nanoscale catalysts for viable biomass conversion. Chem. Soc. Rev. 2019, 48, 2366-2421. [CrossRef] [PubMed]

17. Zhong, S.; Zhuang, J.; Yang, D.; Tang, D. Eggshell membrane-templated synthesis of 3D hierarchical porous Au networks for electrochemical nonenzymatic glucose sensor. Biosens. Bioelectron. 2017, 96, $26-32$. [CrossRef] [PubMed]

18. Park, S.; Park, S.; Jeong, R.; Boo, H.; Park, J.; Chan, H.; Dong, T. Nonenzymatic continuous glucose monitoring in human whole blood using electrified nanoporous Pt. Biosens. Bioelectron. 2012, 31, 284-291. [CrossRef] [PubMed]

19. Yang, Q.; Liang, S.; Han, B.; Wang, J.; Mao, R. Preparation and properties of enhanced bulk nanoporous coppers. Mater. Lett. 2012, 73, 136-138. [CrossRef]

20. Luo, L.; Zhu, L.; Wang, Z. Nonenzymatic amperometric determination of glucose by CuO nanocubesgraphene nanocomposite modified electrode. Bioelectrochemistry 2012, 88, 156-163. [CrossRef]

21. Wu, X.; Li, F.; Zhao, C.; Qian, X. One-step construction of hierarchical $\mathrm{Ni}(\mathrm{OH})_{2} / \mathrm{RGO} / \mathrm{Cu}_{2} \mathrm{O}$ on Cu foil for ultrasensitive non-enzymatic glucose and hydrogen peroxide detection. Sens. Actuators B Chem. 2018, 274, 163-171. [CrossRef]

22. Ding, Y.; Wang, Y.; Su, L.; Bellagamba, M.; Zhang, H.; Lei, Y. Electrospun $\mathrm{Co}_{3} \mathrm{O}_{4}$ nanofibers for sensitive and selective glucose detection. Biosens. Bioelectron. 2010, 26, 542-548. [CrossRef] [PubMed]

23. Liu, M.; Liu, R.; Chen, W. Graphene wrapped $\mathrm{Cu}_{2} \mathrm{O}$ nanocubes: Non-enzymatic electrochemical sensors for the detection of glucose and hydrogen peroxide with enhanced stability. Biosens. Bioelectron. 2013, 45, $206-212$. [CrossRef] [PubMed] 
24. Dhara, K.; Stanley, J.; Ramachandran, T.; Nair, B.G.; Satheesh, S.B. Pt-CuO nanoparticles decorated reduced graphene oxide for the fabrication of highly sensitive non-enzymatic disposable glucose sensor. Sens. Actuators B Chem. 2014, 195, 197-205. [CrossRef]

25. Karuppiah, C.; Velmurugan, M.; Chen, S. A simple hydrothermal synthesis and fabrication of zinc oxide-copper oxide heterostructure for the sensitive determination of nonenzymatic glucose biosensor. Sens. Actuators B Chem. 2015, 221, 1299-1306. [CrossRef]

26. Kong, C.; Lv, J.; Hu, X.; Zhao, N.; Liu, K.; Zhang, X.; Meng, G.; Yang, Z. Template-synthesis of hierarchical $\mathrm{CuO}$ nanoflowers constructed by ultrathin nanosheets and their application for non-enzymatic glucose detection. Mater. Lett. 2018, 219, 134-137. [CrossRef]

27. Xu, D.; Zhu, C.; Meng, X.; Chen, Z.; Li, Y.; Zhang, D.; Zhu, S. Design and fabrication of Ag-CuO nanoparticles on reduced graphene oxide for nonenzymatic detection of glucose. Sens. Actuators B Chem. 2018, 265, 435-442. [CrossRef]

28. Dhara, K.; Ramachandran, T.; Nair, B.G.; Satheesh Babu, T.G. Single step synthesis of Au-CuO nanoparticles decorated reduced graphene oxide for high performance disposable nonenzymatic glucose sensor. J. Electroanal. Chem. 2015, 743, 1-9. [CrossRef]

29. Luo, P.; Prabhu, S.V.; Baldwin, R.P. Constant Potential Amperometric Detection at a Copper-Based Electrode: Electrode Formation and Operation. Anal. Chem. 1990, 62, 752-755. [CrossRef]

30. Zhou, S.; Feng, X.; Shi, H.; Chen, J.; Zhang, F.; Song, W. Direct growth of vertically aligned arrays of $\mathrm{Cu}(\mathrm{OH})_{2}$ nanotubes for the electrochemical sensing of glucose. Sens. Actuators B Chem. 2013, 177, 445-452. [CrossRef]

31. Shackery, I.; Patil, U.; Pezeshki, A.; Shinde, N.M.; Kang, S.; Im, S.; Chan, S. Copper Hydroxide Nanorods Decorated Porous Graphene Foam Electrodes for Non-enzymatic Glucose Sensing. Electrochim. Acta 2016, 191, 954-961. [CrossRef]

32. You, T.; Niwa, O. Characterization and electrochemical properties of highly dispersed copper oxide/hydroxide nanoparticles in graphite-like carbon films prepared by RF sputtering method. Electrochem. Commun. 2002, 4, 468-471. [CrossRef]

33. Yang, J.; Jiang, L.; Zhang, W.; Gunasekaran, S. A highly sensitive non-enzymatic glucose sensor based on a simple two-step electrodeposition of cupric oxide $(\mathrm{CuO})$ nanoparticles onto multi-walled carbon nanotube arrays. Talanta 2010, 82, 25-33. [CrossRef] [PubMed]

34. Nantaphol, S.; Watanabe, T.; Nomura, N.; Siangproh, W. Biosensors and Bioelectronics Bimetallic Pt-Au nanocatalysts electrochemically deposited on boron-doped diamond electrodes for nonenzymatic glucose detection. Biosens. Bioelectron. 2017, 98, 76-82. [CrossRef] [PubMed]

35. Song, J.; Xu, L.; Zhou, C.; Xing, R.; Dai, Q.; Liu, D.; Song, H. Synthesis of graphene oxide based cuo nanoparticles composite electrode for highly enhanced nonenzymatic glucose detection. ACS Appl. Mater. Interfaces 2013, 5, 12928-12934. [CrossRef]

36. Zhang, X.; Sun, S.; Lv, J.; Tang, L.; Kong, C.; Song, X.; Yang, Z. Nanoparticle-aggregated CuO nanoellipsoids for high-performance non-enzymatic glucose detection. J. Mater. Chem. A 2014, 2, 10073-10080. [CrossRef]

37. Luo, S.; Su, F.; Liu, C.; Li, J.; Liu, R.; Xiao, Y.; Li, Y.; Liu, X.; Cai, Q. A new method for fabricating a $\mathrm{CuO} / \mathrm{TiO}_{2}$ nanotube arrays electrode and its application as a sensitive nonenzymatic glucose sensor. Talanta 2011, 86, 157-163. [CrossRef]

38. Fan, G.; Sun, P.; Zhao, J.; Han, D.; De, D.L.N. Alleviating concentration polarization: A micro-three-electrode interdigitated glucose sensor based on nanoporous gold from a mild process. RSC Adv. 2019, 9, 10465-10472. [CrossRef]

39. Hwang, D.; Lee, S.; Seo, M.; Dong, T. Recent advances in electrochemical non-enzymatic glucose sensors e A review. Anal. Chim. Acta 2018, 1033, 1-34. [CrossRef]

40. Hoppe, M.; Ababii, N.; Postica, V.; Lupan, O.; Polonskyi, O.; Schütt, F.; Kaps, S.; Sukhodub, L.F.; Sontea, V.; Strunskus, T.; et al. $\left(\mathrm{CuO}-\mathrm{Cu}_{2} \mathrm{O}\right) / \mathrm{ZnO}: \mathrm{Al}$ heterojunctions for volatile organic compound detection. Sens. Actuators B Chem. 2018, 255, 1362-1375. [CrossRef]

41. Cui, S.; Liu, X.; Sun, Z.; Du, P. Noble Metal-Free Copper Hydroxide as an Active and Robust Electrocatalyst for Water Oxidation at Weakly Basic pH. ACS Sustain. Chem. Eng. 2016, 4, 2593-2600. [CrossRef]

42. Biesinger, M.C.; Lau, L.W.M.; Gerson, A.R.; St, R.; Smart, C. Resolving surface chemical states in XPS analysis of first row transition metals, oxides and hydroxides: Sc, Ti, V, Cu and Zn. Appl. Surf. Sci. 2010, 257, 887-898. [CrossRef] 
43. Mcintyre, N.S.; Cook, M.G. X-Ray Photoelectron Studies on Some Oxides and Hydroxides of Cobalt, Nickel and Copper. Anal. Chem. 1975, 47, 2208-2213. [CrossRef]

44. Au, N.H.C.; Au, I.; Young, A.J.; Sauer, M.; Sato, A.; Foelske, A.; Reithofer, M.R.; Serpell, C.J.; Chin, M. One-step synthesis and XPS investigations of chiral NHC-Au(0)/Au(I) nanoparticles. Nanoscale 2019, 11, 8327-8333.

45. Paixão, T.R.L.C.; Corbo, D.; Bertotti, M. Amperometric determination of ethanol in beverages at copper electrodes in alkaline medium. Anal. Chim. Acta 2002, 472, 123-131. [CrossRef]

46. Wen-zhi, L.; You-qin, L. Preparation of nano-copper oxide modified glassy carbon electrode by a novel film plating/potential cycling method and its characterization. Sens. Actuators B Chem. 2009, 141, 147-153.

47. Wu, H.; Cao, W.; Li, Y.; Liu, G.; Wen, Y.; Yang, H.; Yang, S. In situ growth of copper nanoparticles on multiwalled carbon nanotubes and their application as non-enzymatic glucose sensor materials. Electrochim. Acta 2010, 55, 3734-3740. [CrossRef]

48. Wang, R.; Sun, P.; Wang, H.; Wang, X. Pulsed laser deposition of amorphous molybdenum disulfide films for efficient hydrogen evolution reaction. Electrochim. Acta 2017, 258, 876-882. [CrossRef]

49. Xie, F.; Wu, H.; Mou, J.; Lin, D.; Xu, C.; Wu, C.; Sun, X. Ni H $_{3} \mathrm{~N} @ \mathrm{Ni}-\mathrm{Ci}$ nanoarray as a highly active and durable non-noble-metal electrocatalyst for water oxidation at near-neutral pH. J. Catal. 2017, 356, 165-172. [CrossRef]

50. Qu, Y.; Medina, H.; Wang, S.; Wang, Y.; Chen, C.; Su, T.; Manikandan, A.; Wang, K.; Shih, Y.; Chang, J.; et al.

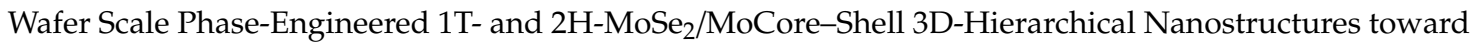
Efficient Electrocatalytic Hydrogen Evolution Reaction. Adv. Mater. 2016, 28, 9831-9838. [CrossRef]

51. Chen, H.; Sun, P.; Qiu, M.; Jiang, M.; Zhao, J.; Han, D.; Niu, L. Co-P decorated nanoporous copper framework for high performance flexible non-enzymatic glucose sensors. J. Electroanal. Chem. 2019, 841, 119-128. [CrossRef]

52. Li, R.; Liu, X.; Wang, H.; Wu, Y.; Lu, Z. High-performance hybrid electrode decorated by well-aligned nanograss arrays for glucose sensing. Biosens. Bioelectron. 2018, 102, 288-295. [CrossRef] [PubMed]

53. Zhang, J.; Ma, J.; Zhang, S.; Wang, W.; Chen, Z. A highly sensitive nonenzymatic glucose sensor based on $\mathrm{CuO}$ nanoparticles decorated carbon spheres. Sens. Actuators B Chem. 2015, 211, 385-391. [CrossRef]

54. Kannan, P.; Maiyalagan, T.; Marsili, E.; Ghosh, S.; Niedziolka-jönsson, J.; Jönsson-niedziolka, M. Hierarchical 3-dimensional nickel-iron nanosheet arrays on carbon fiber paper as a novel electrode for non-enzymatic glucose sensing. Nanoscale 2015, 8, 843-855. [CrossRef]

55. Liu, X.; Long, L.; Yang, W.; Chen, L.; Jia, J. Facilely electrodeposited coral-like copper micro-/nano-structure arrays with excellent performance in glucose sensing. Sens. Actuators B Chem. 2018, 266, 853-860. [CrossRef]

56. Xiao, L.; Chen, Q.; Jia, L.; Zhao, Q.; Jiang, J. Networked cobaltous phosphate decorated with nitrogen-doped reduced graphene oxide for non-enzymatic glucose sensing. Sens. Actuators B Chem. 2019, 283, 443-450. [CrossRef]

(C) 2019 by the authors. Licensee MDPI, Basel, Switzerland. This article is an open access article distributed under the terms and conditions of the Creative Commons Attribution (CC BY) license (http://creativecommons.org/licenses/by/4.0/). 